\title{
Developing Written Mathematics Communication through Solving Analogous Problems
}

\author{
Eka Zulia Ningtyas ${ }^{1}$ Rooselyna Ekawati ${ }^{2}$ \\ ${ }^{1}$ Jl. Ketintang, Kota Surabaya, 60231, Universitas Negeri Surabaya, eka.17030174002@mhs.unesa.ac.id \\ ${ }^{2}$ Jl. Ketintang, Kota Surabaya, 60231, Universitas Negeri Surabaya, rooselynaekawati@unesa.ac.id
}

\begin{abstract}
Developing mathematics communication, especially in writing is needed considering that communication is one of the objectives of learning mathematics which can describe students understanding so that effective strategies are needed to develop it. One of problem solving strategies that can measures written mathematics communication is solving the analogous problem. This research aims to describe the analogous problem in developing mathematics communication especially in written communication. This research was a qualitative type through a student-written test about solving target problem using analogous problems and interview. The result showed solving analogous problems gave students understanding to be able to do the target question correctly also easier than before and it effected students could communicate the correct solutions accurately, effectively and completely in writing. So it can be said that solving analogous problems develops written mathematics communication ability of student effectively.
\end{abstract}

Keywords: written, mathematics communication, analogous problems, problem-solving.

\section{Mengembangkan Komunikasi Matematika Tertulis melalui Pemecahan Masalah Analogi}

\begin{abstract}
ABSTRAK
Mengembangkan komunikasi matematika, lebih tepatnya komunikasi tertulis diperlukan mengingat komunikasi matematika sebagai salah satu tujuan pembelajaran matematika sehingga strategi yang efektif diperlukan dalam mengembangkannya. Salah satu strategi pemecahan masalah yang dapat mengukur komunikasi tertulis siswa adalah dengan meminta siswa menyelesaikan beberapa masalah analogi. Penelitian ini bertujuan untuk mendeskripsikan masalah analogi dalam mengembangkan komunikasi matematika khususnya dalam komunikasi tertulis. Penelitian ini adalah tipe kualitatif melalui tes tertulis siswa tentang penyelesaian masalah target menggunakan masalah analogi dan wawancara. Hasilnya adalah penyelesaian masalah analogi memberikan siswa pemahaman dalam menyelesaikan masalah dengan benar juga siswa merasa lebih mudah menyelesaikan dari sebelumnya dan siswa mampu mengkomunikasikan solusi yang benar secara akurat, efektif dan lengkap dalam tulisan. Jadi dapat dikatakan bahwa memecahkan masalah analogi mengembangkan kemampuan komunikasi matematika tertulis siswa secara efektif.
\end{abstract}

Kata Kunci: tertulis, komunikasi matematika, masalah analogi, pemecahan masalah.

Tanggal Masuk: 29 Juni 2020; Revisi: 8 April 2021; Diterima: 14 April 2021 


\section{Introduction}

Communication is one of goal that has to be reached in learning mathematics., and NCTM [1] said that Communication is considered as an important skill of mathematics learning because it contains sharing and explaining ideas, orally and in writing also tools to clarify understanding [2]. Even though those kind of communication are important, writing is more effective than orally because it leads processes for supporting a metacognitive framework [3], can help students to express their thought in explaining strategies, improving cognitive skills and writing algorithm correctly [4]. In the mathematics learning, writing is seen as a powerful teaching strategy because it ensures that all students participate in the activity and not just the majority. For teachers, students' writing can provide a picture of their students' cognitive and affective.

Studies in written communication have been frequently done in many literatures on mathematics education research. Previous studies of L. Santos reveal that written communication assist in the learning of mathematical concepts and procedural knowledge, until the development of problem-solving skills and metacognitive abilities [3]. Furthermore, she realized that more studies concerning writing in mathematics are required and needed in detail explanation so it would better to understand the contribution of writing in promoting high-order thinking. Communicating in writing can be especially useful to develop students' mathematical understanding. It's a skill that helps students to extract meaning, and to develop complex ideas.

Developing written mathematics communications is one of goals of mathematics lessons in Curriculum 2013 [5] and in concert with the new paradigm of learning mathematics [6]. Writing Aspect in mathematics communication can be raised by the presence of mathematical writing for example in making conclusions or in explaining the ideas and answers. These activities can increase students' skills in writing mathematical ideas. By answering the questions will make students able to recognize things unknown and the known and can improve writing skills for students. Levenson in L. Santos taking into account that giving writing tasks may provide a favorable context for the development of mathematical communication, leading them progressively from informal to more formal explanations [3].

Mathematical communication involves a cognitive process [7] and bolster other mathematical skills, such as problem-solving ability [6]. Measuring mathematics communication skill can be done by giving the student problems to be solved. According to Smieskova, mathematics communication facilitates to improve conceptual understanding so it could help student in solving problems [8]. Students mathematics problem-solving skill [1] can be developed through learning process that including problem-solving activities so it motivate students build new mathematical knowledge through problem-solving, solving problems that appear in mathematics and other contexts, also apply appropriate strategies to solve problems. While the mathematical communication abilities of students [1] can be developed through process that allows all students to organize their mathematical thinking through communication, to communicate their mathematical thinking coherently and clearly, to analyze and evaluate the mathematical thinking and strategies of others, to use the language of mathematics to express mathematical ideas. In other words, problem-solving is a process of mathematical thinking, and to analyze the process and the result, the student must communicate their thinking, that's why by using problem-solving the mathematical communication ability can be measured. According to Qohar, students' mathematical communication especially in written can be developed through encourages students to write mathematically, such as write the solution of problem [6]. On the other hand, consider D Wahyuningrum's 
research result [9], the strength relation between mathematical problem solving and communication can be seen from student's problem-solving abilities and it followed by their mathematical communication skill. Kim and Noh also said that in general there is a consistent linear correlation between problem understanding and problem solving and communication skills [10].

Studies about problem solving strategies are effective to enhance students' abilities in mathematical communication skills [11], and better than other approaches [12]. There are many strategies to solve problems in mathematics. Solving simpler analogous problem is one of problem-solving strategy mentioned Posamentier and Krulik, sometimes turns out to be most revealing is to change the given problem into one of that more easier to solve, and by solving this source problem, gain the insight needed to solve the target problem [13]. Based on T Hidayat's research result, students with various solving problem ability use solving simpler analogous problems as their strategy to find the solution of the problem [14]. This indicates that strategy suitable with every student who has various ability of solving problem and there is possibility to help them improve student's written communication skill. According to Richland, Zur, Holyoak in K. J. Holyoak and L. E. Richland learning by analogy typically involves finding a mapping between a betterknown target analogous and a more novel source [15]. Based on the K. J. Holyoak and L. E. Richland explanation solving simpler problem can trained logic skill because it can emphasise formalisation and calculation [15]. It means that solving simpler problem can guide the student to calculate correctly, to make formal understanding and also communication skill properly. Increasing student's capability to competently solve varied problems in a changing environment is an important objective of education. Result of the study [16] said that students who used the analogical problem strategy well transferring information between analogous target and source problems, using the analogous target problem and applying it to the source problem. Analogical transfer occurs when a specific structural suitability between objects and relations in the target and source is used to adapt the learned solution procedure to become an analog procedure of solving the source problem. [17]. From that, it is possible to improve problem-solving ability by solving source problem. Because written communication has a relation with problem-solving ability, so there is a possibility to improve students' ability in written communication through source problems.

However, the previous studies [13]-[17] described about analogical problem in problem solving process or skills and study about developing mathematics communication [3] didn't connect it with analogical problem. It can be said that there limitation of research or study that connected solving problem using source problem strategy with the written mathematics communication. This study describe analogous problem in developing mathematics communication, especially in written communication. The research questions of this study are (1) is solving analogous problems can develop written mathematics communication? (2) How effective using analogous problem strategy in developing students' written mathematical communication?

\section{Method}

\subsection{Sample of Method}

In this research data was analyzed qualitatively. This study involved the $11^{\text {th }}$ grade (aged 16-17) as many as 15 students from a school in Gresik with various backgrounds in terms of gender, mathematics ability that had been categorized as high, middle, low ability based on their final grade, participated to do test consisting of one target problem 
and seven source or analogous problems examining their written mathematical communication ability. There are two sections test. They were asked to do the test in 15 minutes in the first section then 20 minutes in the second section. They were also informed that their work would not be graded so that they could use their methods to solve the tasks. As many as two samples were recruited by considering the same gender as the control variable and willingness to participate. Last, they were interviewed about their work.

\subsection{Instrument}

Data were collected mainly through (i) participant observation in which the students solve problems without any clue or hints (ii) participant observation which the students solved problems with some analogies problem. (iii) semi-structured interviews textrecorded, with each participant student. The target problem was arranged by the authors based on common students' difficulty. Difficulties in mathematics skills were classified into arithmetic, number fact, language, information, and visual-spatial skills but the information skills which expertise to connect information to a concept, operational, and experience as well the expertise to transfer information and transform problems into mathematical sentence was the most critical [18]. The source problems also arranged by considering mathematics concepts that are similar to target problems. See those instruments for this research in picture 1 .

\section{TARGET PROBLEM}

Given a polynomial with degree $\mathrm{n}$, with $a_{n} \neq 0$ and $n \in \mathrm{N}$

$$
\begin{aligned}
& P(x)=a_{n} x^{n}+a_{n-1} x^{n-1}+a_{n-2} x^{n-2}+a_{n-3} x^{n-3}+\cdots+a_{2} x^{2}+a_{1} x+a_{0} \\
& Q(x)=a_{0} x^{n}+a_{1} x^{n-1}+a_{2} x^{n-2}+a_{3} x^{n-3}+\cdots+a_{n-2} x^{2}+a_{n-1} x+a_{n}
\end{aligned}
$$

How are the roots of the polynomial $\mathrm{P}(\mathrm{x})$ and $\mathrm{Q}(\mathrm{x})$ roots above? Write all your ideas about the relationship between roots.

\section{SOURCE PROBLEMS}

If you find it difficult and doubt with your answer, solve the questions below!

1. Determine the roots of $x^{2}-x-12=-6$

2. Determine the roots of $x^{2}-x-6$

3. Determine the roots of $-6 x^{2}-x+1$

4. What are the roots of the equation in number 2 and number 3 ?

5. Determine the roots of $x^{3}-3 x^{2}-4 x+12$

6. Determine the roots of $12 x^{3}-4 x^{2}-3 x+1$

7. What are the roots of the equation in number 5 and number 6 ?

Have you found the relationship between the root polynomial target problems from solving some of the problems above? If you have found a relationship, complete the target problem above!

Picture 1 Test Instrument

Table 1 describes the interview protocol that guided the interviewer to collect data. This protocol interviews were supposed to understand and confirm subjects' perspectives regarding the development of their written mathematics communication using source problem strategy and the effectiveness using source problem strategy in developing 
written mathematical communication. However, this protocol does not mean to guide the interviewers to use all the question items too rigidly.

TABLE 1 Protocol for Interviewing The Subjects.

\begin{tabular}{|c|c|}
\hline Observing & Example of Item Question \\
\hline 1. Understanding problem & $\begin{array}{l}\text { Do you understand the purpose of the target problem? Explain in } \\
\text { your word! }\end{array}$ \\
\hline 2. Difficulties & $\begin{array}{l}\text { Are you having trouble finding a solution to the target problem? } \\
\text { When given a mathematical problem, is it usually easy for you to } \\
\text { find solutions and express solutions or solutions? }\end{array}$ \\
\hline 3. Opinion & $\begin{array}{l}\text { How do you feel after being given the target problems before } \\
\text { being told to solve some of the problems below? }\end{array}$ \\
\hline 4. Role of Source problem & $\begin{array}{l}\text { Does solving the problems below the target problem help you find } \\
\text { an idea or solution to the solution above? } \\
\text { Does solving the source problems below the target problem help } \\
\text { you improve your ability to communicate your solution? } \\
\text { What is the role of helper questions in giving the target problem- } \\
\text { solving solution in your opinion? }\end{array}$ \\
\hline
\end{tabular}

Adapted from [19] the indicators of mathematical problem-solving abilities in this study are (1) understanding problems (identifying problem); (2) solving problems with chosen strategy and plan; (3) answer the problem. The score of mathematical problemsolving ability given as in table 2 by adopted the rubric from [9].

TABLE 2 Item Scoring Guidelines Test of Mathematical Problem Solving Ability.

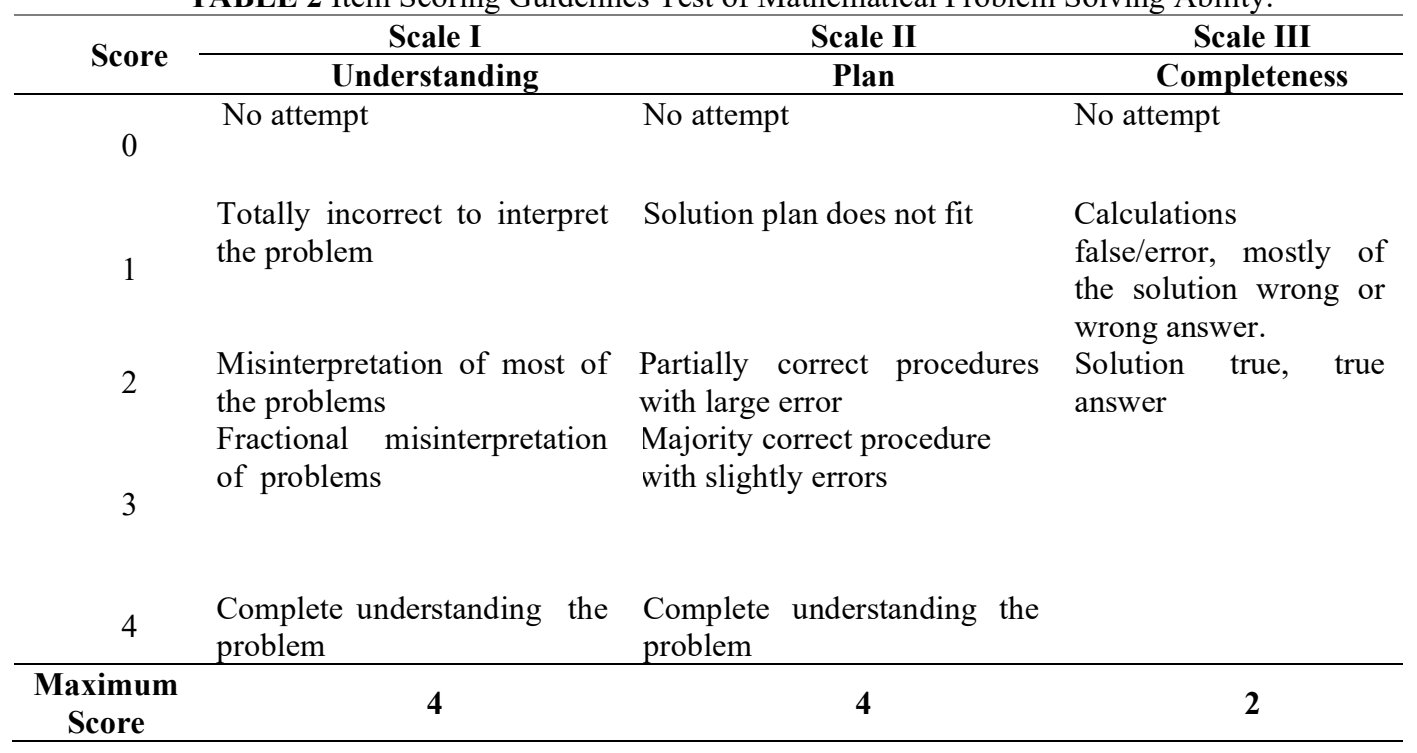

The indicator of analogy transfer based focus on (i) the accuracy of students' work, (ii) ability to recognizing equivalent representations of the same concept, (iii) ability to recognize the relationship of mathematical procedures to a representation to equivalent representation procedures. Analogy transfer indicate the increasing in either use of that procedure or accuracy, so it would be effective for problems that must be solved with particular procedure, e.g., the probability problems used by Ross, 1987; the tumor 
Eka Zulia Ningtyas, Rooselyna Ekawati

problem used by Gick \& Holyoak, 1980, 1983 in [17]. Scoring to analogy transfer given as in table 3 . 
TABLE 3 Item Scoring Guidelines Analogy Transfer.

\begin{tabular}{|c|c|c|c|c|}
\hline \multirow{3}{*}{ Score } & \multicolumn{2}{|r|}{ Scale I } & Cosle I & Scolo U \\
\hline & \multirow{2}{*}{\multicolumn{2}{|c|}{ Accuracy }} & & \\
\hline & & & Concept & Procedures \\
\hline 0 & \multicolumn{2}{|c|}{ No attempt } & No attempt & \multirow{3}{*}{$\begin{array}{l}\text { No attempt } \\
\text { Wrong recognize the relationship } \\
\text { of mathematical procedures to a } \\
\text { representation to equivalent } \\
\text { representation procedures } \\
\text { Correct recognize the relationship } \\
\text { of mathematical procedures to a } \\
\text { representation to equivalent } \\
\text { representation procedures }\end{array}$} \\
\hline 1 & $\begin{array}{l}\text { Answer } \\
\text { accurate } \\
\text { problem } \\
\text { problem }\end{array}$ & $\begin{array}{c}\text { wrong and not } \\
\text { solving source } \\
\text { and target }\end{array}$ & $\begin{array}{l}\text { Wrong recognizing } \\
\text { equivalent representations } \\
\text { of the same concept }\end{array}$ & \\
\hline 2 & $\begin{array}{l}\text { Answer } \\
\text { accurate } \\
\text { problem } \\
\text { problem }\end{array}$ & $\begin{array}{cr}\text { correct } & \text { and } \\
\text { solving } & \text { source } \\
\text { and } & \text { target }\end{array}$ & $\begin{array}{l}\text { Correct recognizing } \\
\text { equivalent representations } \\
\text { of the same concept }\end{array}$ & \\
\hline $\begin{array}{c}\text { Maximum } \\
\text { Score }\end{array}$ & \multicolumn{2}{|r|}{2} & 2 & 2 \\
\hline
\end{tabular}

The indicator [20] shows mathematical communication for oral communication is (i) explain the math language such as symbol and notation, (ii) explain and evaluate mathematical idea, (iii) present the solution of a problem, (iv) explain the conclusion obtained and for written communication (i) write mathematical language such as symbol and notation correctly, (ii) illustrates the problem situation visually, (iii) represent the mathematics concepts and solutions, (iv) state the solution in written form and their word. Nevertheless, this study only focus on students' mathematical communication ability in writing, so it uses the indicators of written mathematical communication skills [20]. The score of written communication ability is given of zero to four scale which is adopted from [9] shown in table 4. Besides that, the Indicator of developing written mathematics communication skills shows when students get a score of Mathematical Communication Ability higher than their previous work in solving the same problem and make a conclusion.

TABLE 4 Item Scoring Guidelines Test of Mathematical Communication Ability.

\begin{tabular}{cl}
\hline Score & Mathematical Communication Ability in Writing \\
\hline 0 & $\begin{array}{l}\text { Empty, or answer is not enough to get a score } \\
\text { The answer incorrect, wrong attempt. }\end{array}$ \\
2 & $\begin{array}{l}\text { Write and use mathematical language such as, symbols, signs, terms and or representations } \\
\text { minimally effective, accurate to describe operations, concepts, and process correctly }\end{array}$ \\
& $\begin{array}{l}\text { Write and use mathematical language such as terms, symbols, signs and or representations } \\
\text { mostly effective, accurate, and thorough to describe concepts, processes and operations } \\
\text { correctly }\end{array}$ \\
& $\begin{array}{l}\text { Write and use mathematical language such as terms, symbols, signs and or representations } \\
\text { very effective, accurate, and thorough, to describe concepts, processes and operations } \\
\text { correctly }\end{array}$ \\
\hline
\end{tabular}

\subsection{Data Analysis}

Data on subjects' work analyzed using indicators that mentioned before. There are two kinds of data, solving target problem before the given source problem and solving the target problem after a given source problem. For the first data, it will analyze for problem solving ability and written mathematical communication ability before given analogous problems. Then for the next data it will analyze for problem-solving ability and written mathematical communication ability after given analogous problems also the analogy transfer. The data analysis steps include: data reduction, data presentation, and data verification. The conclusions in qualitative research are expected to be new findings that have not previously existed, especially in this research is the effectiveness of analogous problem strategy in developing mathematics communication. 


\section{Result and Discussion}

The research observed two students namely S1 and S2 that have been chosen by considering the same gender, high mathematics ability and their willingness to participate. Mathematics problem-solving ability (code PS), for understanding code PS I, Plan code PS II, Complete code PS III. For analogy transfer (code AT), accuracy code AT I, Concept code AT II, Procedure code AT III. Then written mathematical communication ability namely MC. It also supported by students' interviews.

\subsection{S1 Works}

Before given source problems

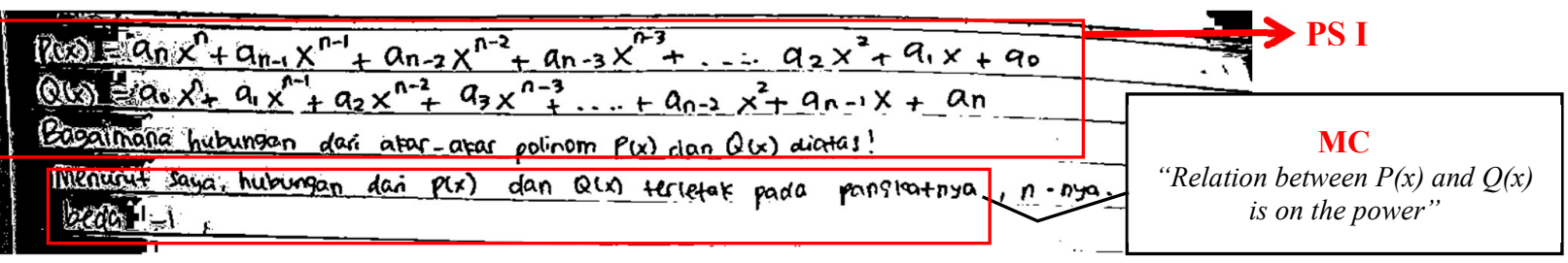

Picture 2 Answer of S1 Before Given Source Problems

Based on picture 2, it can be identified that $\mathrm{S} 1$ understood the problem by wrote the things that are known and asked from the problem as seen in code PS I. This was also shown in the interview between the authors and S1. See the transcript of the interview in picture 3 .

A: Do you understand the purpose of the target problem?

$\mathrm{S} 1$ : yes, I do. The target problem asks the relation of each root of those two equations.

Picture 3 Interview about Understanding S1

Next, in carrying out the plans, it couldn't see in her work. Then, the author conducts an interview related to the obstacle faced so that the $\mathrm{S} 1$ does not write down her plans in solving the problem. See the transcript of the interview in picture 4.

A: Are you having trouble finding a solution to the target problem?

$\mathrm{S} 1$ : yes, actually the form of the problem which no number in it makes me difficult to find the relation of those roots.

A: When given a mathematical problem, is it usually easy for you to find solutions and express solutions or solutions?

S1: I rarely find it difficult to solve mathematical problems especially when determining the roots of an equation

Picture 4 Interview about S1 Plan

From this interview could be identified that $\mathrm{S} 1$ had difficulty in finding ways to find the roots of the equation contained in the target problem. It caused her answer wrong and inappropriate with the solution requested in the problem. However, S1 still described and explained the result in written form and in her words see code MC. 


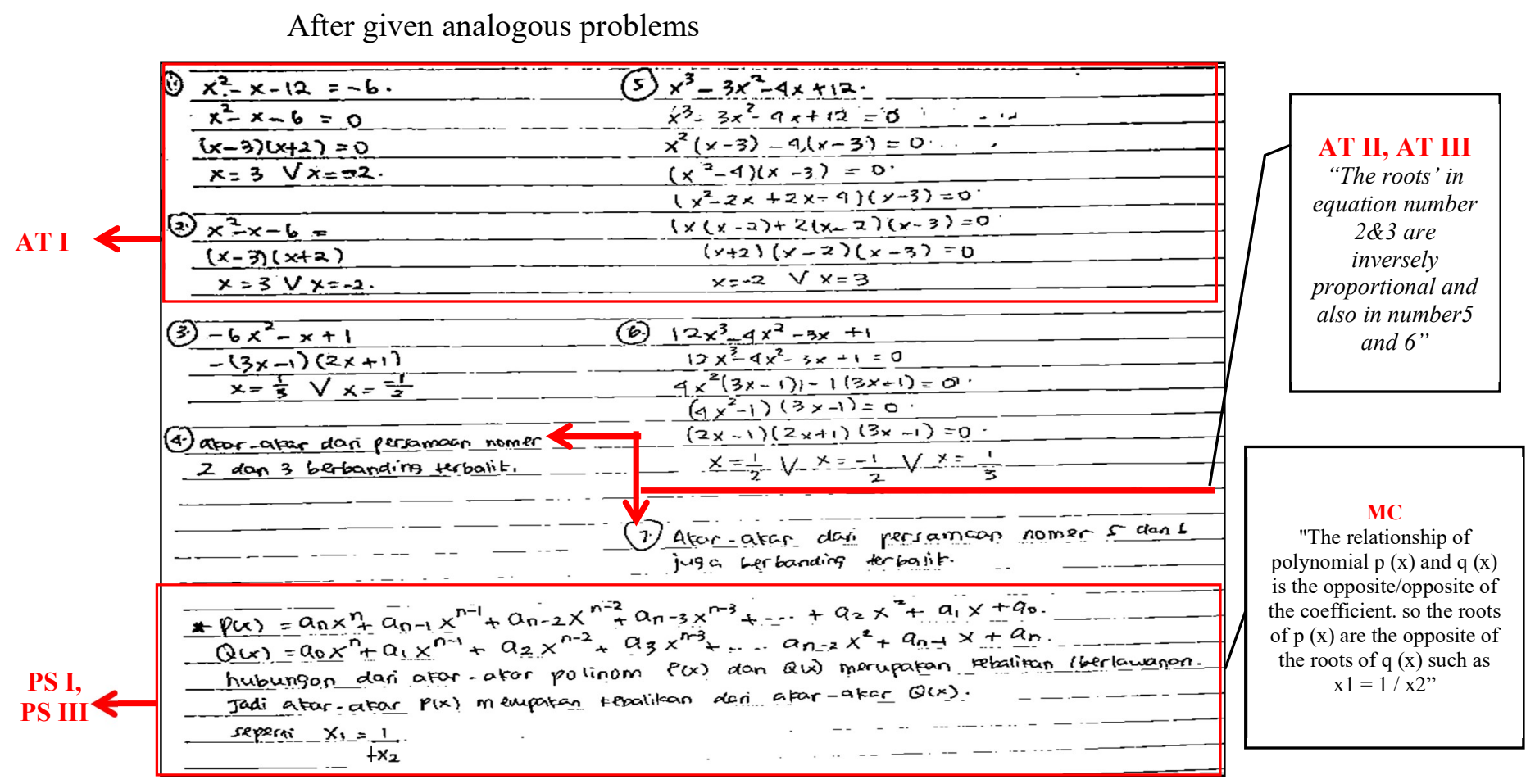

Picture 5 Answer of S1 After Given Source Problems

Based on picture 5, S1 could solve all problems in analogous problems correctly and accurately, look at code AT I. Also, S1 also could describe the relation of roots in quadratic equation and a polynomial with degree three effectively and correctly. It means that S1 could recognize equivalent representations of the same concept also could recognize the relationship of mathematical procedures to a representation to equivalent representation procedures, look at code AT II and AT III. It was also shown in the interview. See the transcript of the interview about the role source or analogous problem for $\mathrm{S} 1$ in picture 6 .

A: Does solving the source problems help you find an idea or solution to the solution of target problem? S1: of course, those problems inspire me.

A: What is the role of source or analogous problems in solving the target problem in your opinion? S1: the analogous problems help me to find the idea, find the relation of roots in target problem. Because the equation form in source or analogous problem has the same form as the target problem.

Picture 6 Interview about Role of Analogous Problem for S1

Then, in solving target problem, S1 understood the problem by writing the things that are known and $\mathrm{S} 1$ also writes the answer solutions from the target of the problem correctly and completely, look at the code PS I and PS III. Unfortunately, S1 still did not write her plan in solving target problem but indirectly when $\mathrm{S} 1$ resolved the source problem then she already had and carried out his plan to solve the target problem. In written mathematical communication skill (MC), S1 used and wrote mathematical language (symbol and notation) appropriately shown in describing the relationship of roots which were inversely proportional to fractions form, also declared the result in written form and explain it in her word. By solving source problem, S1 stated that it could help her to improve the communication skill. See the transcript of the interview in picture 7 . 
A: How do you feel after being given the target problems before being told to solve some of the problems below?

S1: I was confused.

A: Does solving the analogous problems below the target problem help you improve your ability to communicate your solution?

S1: yes, exactly I can write and explain the solution clearly.

Picture 7 Interview about S1 Opinion in Developing Communication Skills

Score of mathematics problem-solving ability and written mathematical communication skill of S1's work before and after given source problems also analogy transfer after given source problems based on score guidelines that have been mentioned before shown in the table 5 .

TABLE 5 Score of S1's Work.

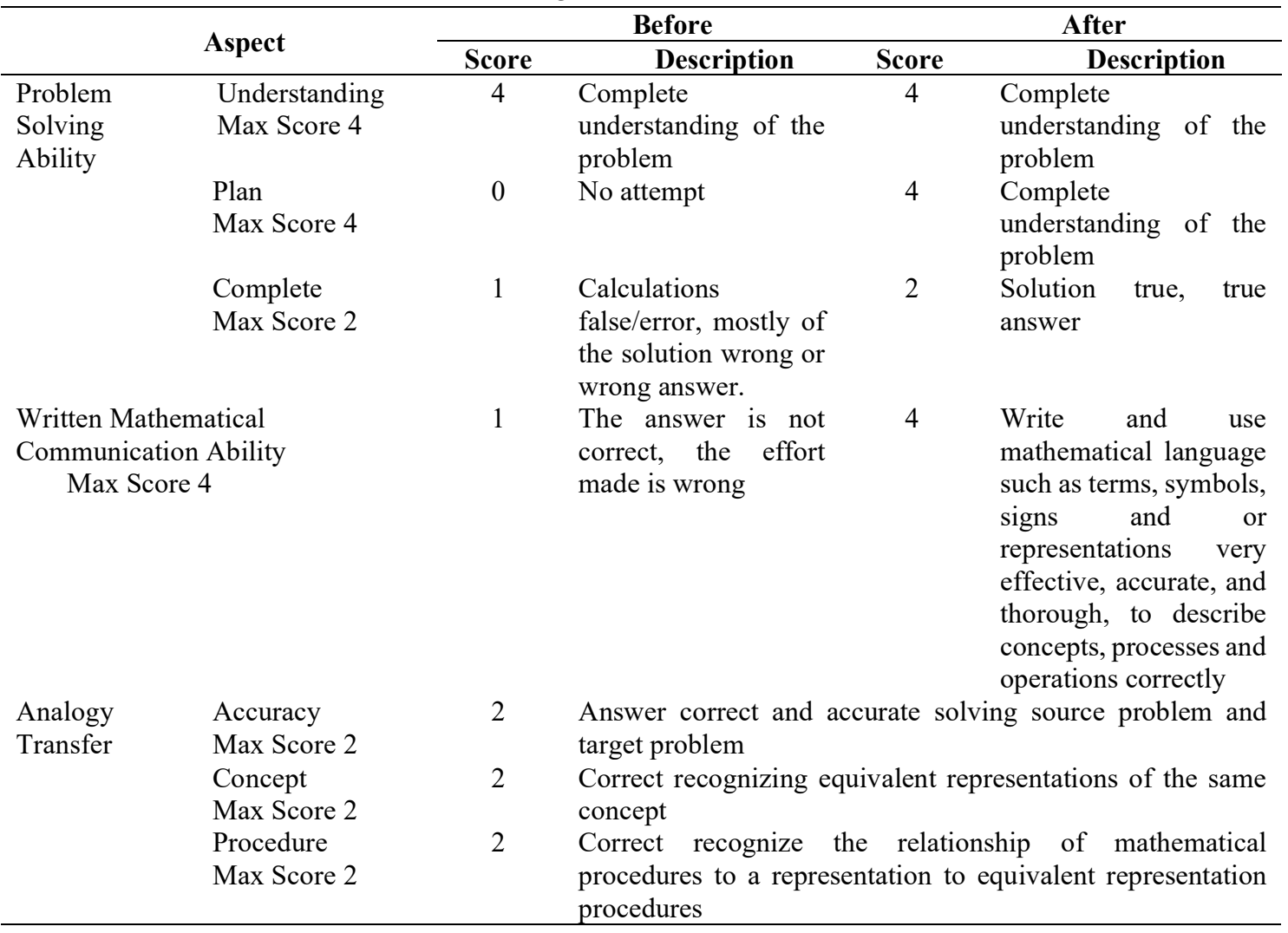

Based on the data in the table, there are significant differences in scores on problemsolving skills and written mathematical communication skills. Initially S1 couldn't answer and explain the source problem solution correctly but after being given a problem the target S1 could answer correctly even communicated the answer solution effectively and accurately. The problem-solving ability and communication skills of written mathematics in S1 tend to increase. This indicates that by solving problems using analogous strategy can improve the ability of $\mathrm{S} 1$ in solving problems and communicating ideas. Indirectly, by working on problems using analogous problem strategies can improve S1's written mathematics communication skills. Improvement of S1 problemsolving skills and written mathematical communication skills occur after given a source problem. This indicates if there is an analogy transfer so that the target problem can be solved following the maximum score obtained by $\mathrm{S} 1$ in the data analogy transfer. 


\subsection{S2 Works}

Before given source problems

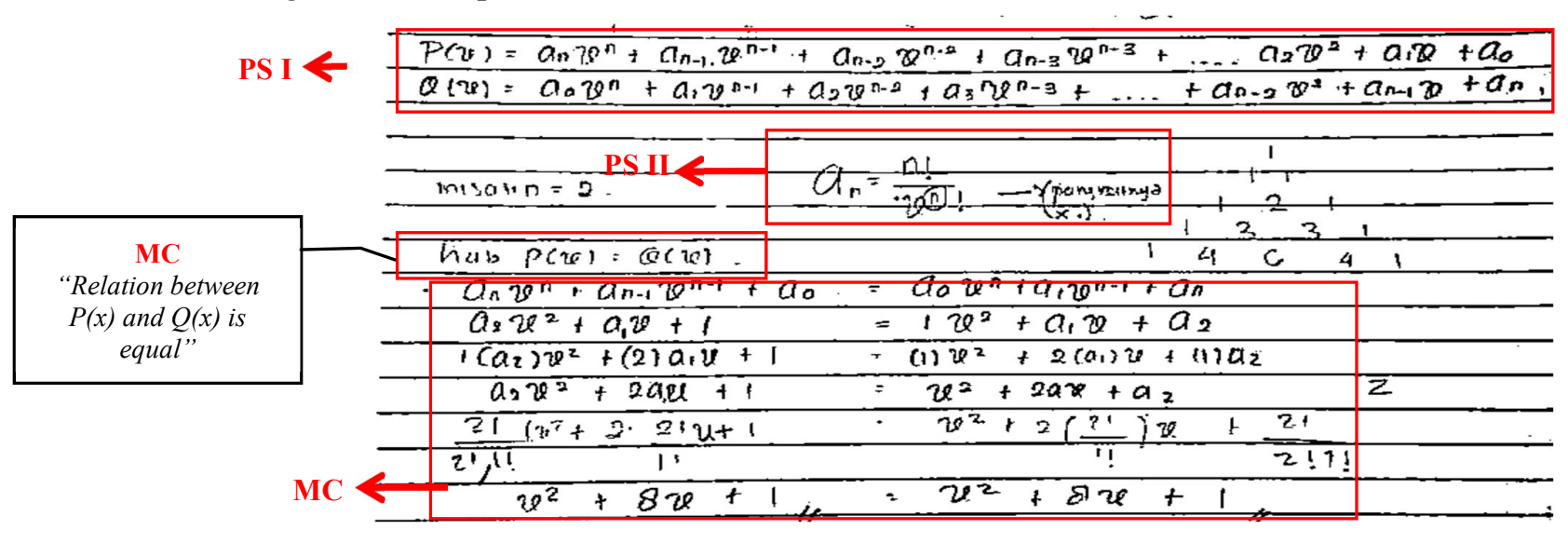

Picture 8 Answer of S2 Before Given Source Problems

Based on picture 8, S2 wrote the things that are known in PS I. S2 also wrote the plan for PS II code in determining the relationship of P (x) and Q (x) into formula form. S2 also explained one form of the polynomial. But here we see the position misunderstanding of S2. The form of equations $\mathrm{P}(\mathrm{x})$ and $\mathrm{Q}(\mathrm{x})$ is a general form that can be replaced by any number that satisfies the shape and conditions of the polynomial. Then the problem asks for the relationship of the roots of the equation not the relation of the form of the equation but S2 just focused on the relation of polynomial form. Therefore, it can be seen if S2 misunderstood the target problem that impacted his plans being wrong and the answers he wrote were also wrong. It also shown in the interview between the authors and S2, actually S2 confused about the target problem. See the transcript of the interview in picture 9 .

A: Do you understand the purpose of the target problem?

S2: yes, I do but I'm not sure with my understanding.

A: Are you having trouble finding a solution to the target problem?

S2: yes, because I'm trouble in understanding the form of the equation.

A: When given a mathematical problem, is it usually easy for you to find solutions and express solutions or solutions?

S2: No

Picture 9 Interview about S2 Understanding Target Problem

Viewed from indicators of written mathematical communication, S2 used and wrote mathematical language (symbol and notation) appropriately. S2 also used a through representation to express the mathematical concepts and solutions. S2 declared the result in written form and her word but unfortunately her answer did not correspond to what in the question, see code MC in S2 works. 
After given analogous problems
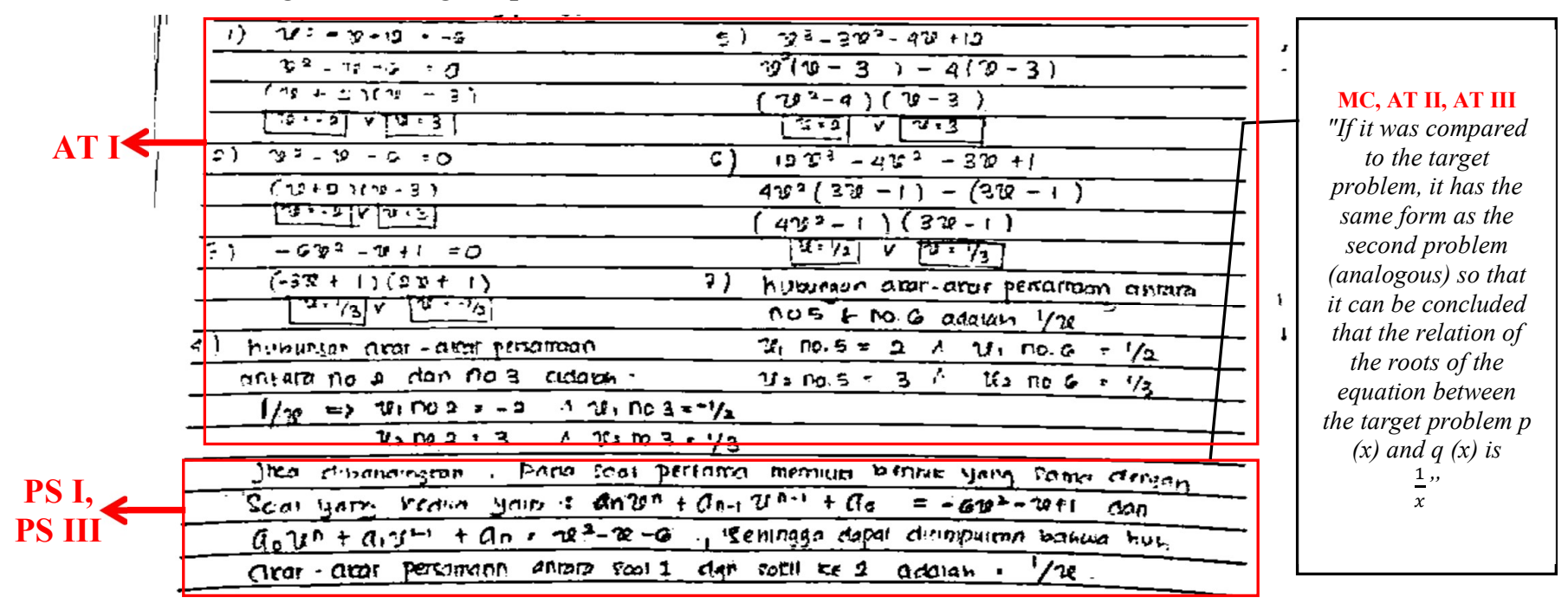

Picture 10 Answer of S2 After Given Source Problems

Based on picture 10, S2 could solve all source or analogous problems correctly and accurately, look at code AT I. Also, S2 could describe the relation of roots of the equation effectively and correctly. It means that $\mathrm{S} 2$ could recognize equivalent representations of the same concept also could recognize the relationship of mathematical procedures to a representation to equivalent representation procedures, Look at code AT II and AT III, S2 were comparing source problems and target problem because those have the same form. It was also shown in the interview. See the transcript of the interview about the role source or analogous problem for S2 in picture 11.

A: Does solving the source or analogous problems help you find an idea or solution to the solution of target problem?

S2: Yes, really helpful.

A: What is the role of analogous problems in solving the target problem in your opinion?

S2: the analogous problems really help me to find the idea for target problem. Because the analogous problem has a relation with the target problem or it has the same pattern as the target problem.

Picture 12 Interview about Role of Analogous Problem for S2

Then, in solving the target problem, S2 understood that the source problem had a suitable form and is similar to the target problem. S1 also wrote the answers from the target of the problem correctly, look at the code PM I and PM III. Even though, S2 did not write her plan in solving target problem but indirectly when S2 resolved the source problem then she already had and carried out his plan to solve the target problem. In written mathematical communication skill (MC), S2 used and wrote mathematical language (symbol and notation) appropriately shown in describing the relationship of roots which were inversely proportional to fractions form, S2 illustrated the problem situation visually and used a through representation to express the mathematical concepts and solutions. Also she declared the result in written form and explained it in her word.

A: How do you feel after being given the target problems before being told to solve source problems?

S2: hard to find the relation root of two equations in the target problem.

A: Does solving the source or analogous problems below the target problem help you improve your ability to communicate your solution?

S2: yes, it does

Picture 11 Interview about S2 Opinion in Developing Communication Skills 
By solving the source problem, S1 stated that it could help her to improve the communication skill. See the transcript of the interview in picture 12.

Score of mathematics problem-solving ability and written mathematical communication skill of S2's work before and after given source problems also analogy transfer after given source problems based on score guidelines that have been mentioned before shown in the table 6 .

TABLE 6 Score of S2's Work.

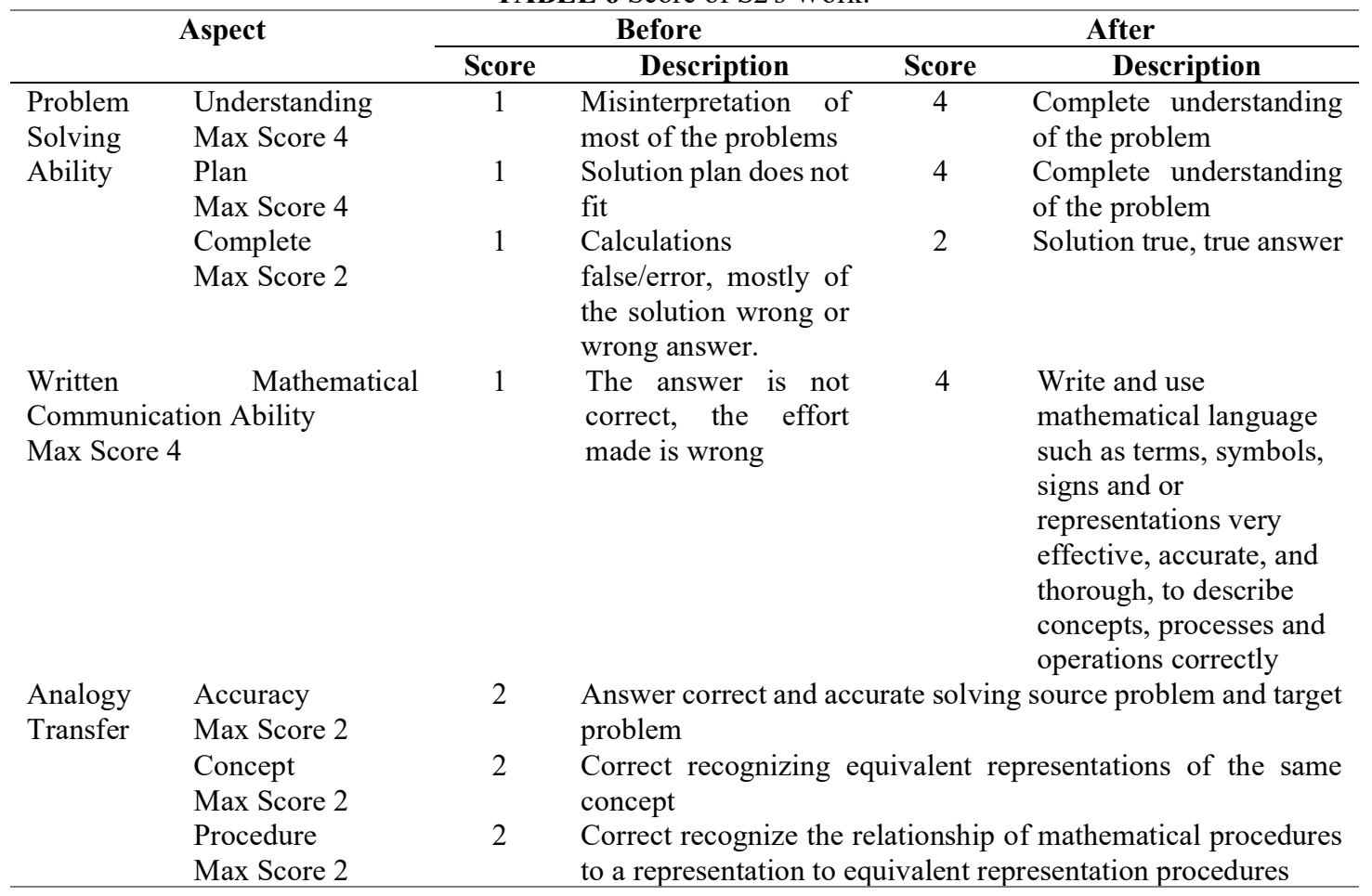

The data in the table shows an increasing of problem-solving skills scores as well as S2 written mathematics communication skills. At first the S2 had difficulty understanding the source problem but after being given a target problem he finally understood the problem and was able to find the right solution. S2's written mathematical communication skills are quite good but unfortunately the answer written is not suitable and correct but after working on the target problem, S2 can communicate the correct answer well. The maximum score obtained by S2 in analogy transfer contributes to finding the correct solution to the target problem because S2 can recognize equivalent representations of the same concept and able to recognize the relationship of mathematical procedures to a representation to equivalent representation procedures. Therefore, S2 can answer and communicate the solution to the target problem better than before being given the source problem. This develops the ability of S2 to solve problems as well as written mathematical communication skills.

The results of this study showed that the enhancement in problem solving and mathematics communication score which means the development of students' written mathematical communication skills in line with improving students' ability to solve problems. The improvement is obtained after students solve several problems that are analogous to the source problem they want to solve. An increasing ability to solve the source problem following the theory of strategies to solve the problem the analogy that can help students solves a problem. This result also supports previous statements, such as Mathematical communication has an important role in learning mathematics, because 
through mathematical communication students can express, explain, explain, hear which brings students to a deep understanding of mathematics [21]. According [19] there was a very significant influence on mathematical communication and mathematical connections to problem-solving abilities. In this study, Analogous problems have contributed to increasing the subject's ability to solve problems and communicating correct solutions accurately so that they have indirectly developed communication skills. According to [16] students with the analogical problem construction strategy perform better at transferring analogical problem information between analogous target and source problems, taking the analogous target problem and applying the taken analogous information to the source problem. Based on the analysis and its relation to relevant research, it can be said by giving students analogous problems to be solved can help students solve target or the complex problems more correctly, effectively and more easily for them or in another sense their ability to solve problems is increased. It also affects their written communication skills, students are able to write solutions correctly and use mathematical language or representations is very effective, accurate, and describe operations, concepts, and processes correctly. In other words, through solving analogous problems would improve problem-solving ability and developing mathematical communication effectively so through analogous problems can be used as a strategy to develop students' written mathematics communication.

\section{Conclusion}

In conclusion, solving the analogous problem can develop written mathematics communication based on enhancement of written mathematics communication score of both subjects. That strategy also able developing students' written mathematical communication effectively because initially the two subjects could not write down the answers correctly but after being given analogous problems they were able to answer the questions correctly and completely. By solving the analogous problems it offers idea for student to understand the problem and solving the problem correctly. As a result, they help students explain the solution clearly. Therefore, it can be said that solving the analogous problem can develop students' written mathematics communication effectively.

\section{References}

[1] National Council of Teachers of Mathematics, Principles and Standards for School Mathematics, First Edit. National Council of Teachers of Mathematics, 2000, 2000.

[2] N. S. R. Rohid and D. Retno, "Students' Mathematical Communication Skills (MCS) in Solving Mathematics Problems: A Case in Indonesian Context.," Anatol. J. Educ., vol. 4, no. 2, pp. 19-30, Oct. 2019.

[3] L. Santos and S. Semana, "Developing mathematics written communication through expository writing supported by assessment strategies," Educational Studies in Mathematics, vol. 88, no. 1. Kluwer Academic Publishers, pp. 65-87, 2015, doi: 10.1007/s10649-014-9557-z.

[4] S. and S. Sumaji, C Sa'dijah, "Students' problem in communicating mathematical problem solving of Geometry," IOP Conf. Ser. Earth Environ. Sci., vol. Volume 243, 2019, doi: 10.1088/1755-1315/243/1/012128.

[5] Kementrian Pendidikan dan Kebudayaan RI, "STANDART ISI Kurikulum 2013 PERMENDIKBUD No.21,” Jakarta, 2016. [Online]. Available: https://bsnpindonesia.org/standar-isi/. 
[6] A. Qohar, "Mathematical Communication: What And How To Develop It In Mathematics Learning? - Lumbung Pustaka UNY," Proc. Int. Semin. Fourth Natl. Conf. Math. Educ., no. ISSN 978-979-16353-7-0, 2011, Accessed: Jun. 25, 2020. [Online]. Available: https://eprints.uny.ac.id/354/.

[7] E. F. Y. Yang, B. Chang, H. N. H. Cheng, and T. W. Chan, "Improving pupils' mathematical communication abilities through computersupported reciprocal peer tutoring," Educ. Technol. Soc., vol. 19, no. 3, pp. 157-169, 2016, [Online]. Available: www.jstor.org/stable/jeductechsoci.19.3.157.

[8] E. Smieskova, "Communication Students' Skills as a Tool of Development Creativity and Motivation in Geometry," Univers. J. Educ. Res., vol. 5, no. 1, pp. 31-35, Jan. 2017, doi: 10.13189/ujer.2017.050104.

[9] D. Wahyuningrum, Endang and Suryadi, "Association of Mathematical Communication and Problem Solving Abilities: Implementation of MEAs Strategy in Junior High School," SAINSAB, vol. 17, no. ISSN 15115267, pp. 3850, 2014, [Online]. Available: http://repository.ut.ac.id/id/eprint/4580.

[10] M. K. Kim and S. Noh, "Alternative Mathematics Assessment: A Case Study of the Development of Descriptive Problems for Elementary School in Korea," Eurasia J. Math. Sci. Technol. Educ., vol. 6, no. 3, pp. 173-186, Dec. 2010.

[11] N. M. Hutapea, S. Saragih, and S. Sakur, "Improving Mathematical Communication Skills of SMP Students Through Contextual Learning," J. Phys. Conf. Ser., vol. 1351, no. 1, 2019, doi: 10.1088/1742-6596/1351/1/012067.

[12] H. Tambunan, "The Effectiveness of the Problem Solving Strategy and the Scientific Approach to Students' Mathematical Capabilities in High Order Thinking Skills," vol. 14, no. 2, pp. 293-302, 2019, doi: 10.29333/iejme/5715.

[13] S. Posamentier, A S and Krulik, Problem Solving Strategies for Efficient and Elegant Solutions : A Resourches for The Mathematics Teacher. California: CORWIN PRESS INC, 1998.

[14] T. Hidayat, "Strategi Mahasiswa dalam Memecahkan Permasalahan Non Rutin pada Materi Aljabar,” 2017, Accessed: Jun. 13, 2020. [Online]. Available: http://eprints.ums.ac.id/id/eprint/53043.

[15] K. J. Holyoak and L. E. Richland, "Using analogies as a basis for teaching cognitive readiness," in Teaching and Measuring Cognitive Readiness, vol. 9781461475, Springer US, 2014, pp. 223-238.

[16] A. B. I. Bernardo, "Overcoming obstacles to understanding and solving word problems in mathematics," Int. J. Phytoremediation, vol. 19, no. 2, pp. 149-163, 1999, doi: 10.1080/0144341990190203.

[17] L. R. Novick and K. J. Holyoak, "Mathematical Problem Solving by Analogy," J. Exp. Psychol. Learn. Mem. Cogn., vol. 17, no. 3, pp. 398-415, 1991, doi: 10.1037/0278-7393.17.3.398.

[18] T. Tambychik and T. S. M. Meerah, "Students' difficulties in mathematics problem-solving: What do they say?," in Procedia - Social and Behavioral Sciences, Jan. 2010, vol. 8, pp. 142-151, doi: 10.1016/j.sbspro.2010.12.020.

[19] Suharto and W. Widada, "The Contribution of Mathematical Connection and Mathematical Communication to Problem Solving Ability," 2019.

[20] S. S, Puspa, R, Riyadi and S, "Profile of mathematical communication skills junior high school students in problem solving," J. Phys. Conf. Ser., vol. 1157, no. 3, 2017, doi: https://doi.org/10.1088/1742-6596/1157/3/032125.

[21] P. Paridjo and S. B. Waluya, "Analysis Mathematical Communication Skills Students In The Matter Algebra Based Nctm," IOSR J. Math., vol. 13, no. 01, pp. 60-66, Feb. 2017, doi: 10.9790/5728-1301056066. 